\title{
The Impact of Corporate Governance Mechanism over Financial Performance: Evidence from Romania
}

\author{
Tatiana Dănescu ${ }^{1, *}$, Ioan-Ovidiu Spătăcean ${ }^{1}$, Maria-Alexandra Popa ${ }^{1}\left(\mathbb{O}\right.$ and Carmen-Gabriela Sîrbu ${ }^{2} \mathbb{D}$ \\ 1 Faculty of Economics and Law, "George Emil Palade” University of Medicine, Pharmacy, Science and \\ Technology of Târgu Mureș, 540142 Târgu Mureș, Romania; ovidiu.spatacean@umfst.ro (I.-O.S.); \\ maria.popa@umfst.ro (M.-A.P.) \\ 2 Faculty of Economic Sciences, Danubius University of Galati, 800654 Galați, Romania; \\ carmensirbu@univ-danubius.ro \\ * Correspondence: tatiana.danescu@umfst.ro; Tel.: +40-740223941
}

\section{check for} updates

Citation: Dănescu, T.; Spătăcean, I.-O.; Popa, M.-A.; Sîrbu, C.-G. The Impact of Corporate Governance Mechanism over Financial

Performance: Evidence from Romania. Sustainability 2021, 13, 10494. https://doi.org/10.3390/ su131910494

Academic Editors:

Adriana Tiron-Tudor and

Giuseppe Nicolò

Received: 23 August 2021

Accepted: 18 September 2021

Published: 22 September 2021

Publisher's Note: MDPI stays neutral with regard to jurisdictional claims in published maps and institutional affiliations.

Copyright: (c) 2021 by the authors. Licensee MDPI, Basel, Switzerland. This article is an open access article distributed under the terms and conditions of the Creative Commons Attribution (CC BY) license (https:/ / creativecommons.org/licenses/by/ $4.0 /)$.

\begin{abstract}
In the context of the globalization and internationalization of economies, to efficiently attract financial and intellectual capital that is necessary for business sustainability, the mechanisms of corporate governance have to be based on gaining the trust of all the interested parties. These objectives require an organizational culture and a climate which is based on correctness, responsibility, transparency, and efficiency, in which ethical principles govern the spread of behaviors in the entire entity. This research identifies the relation between the corporate governance and the entities' financial performance using the specific context of Romania. The findings of this study reveal new insights on the corporate governance and financial performance based on a sample of companies listed on the Bucharest Stock Exchange. The results show a positive correlation between the net accounting results, earnings per share, and the duality of the $\mathrm{CEO}$, and a negative correlation between price per share and the duality of the CEO.
\end{abstract}

Keywords: corporate governance; financial performance; transparency; sustainable financial reports; board of directors effectiveness; emerging markets; OLS; Bucharest Stock Exchange (BSE)

\section{Introduction}

The application of principles, rules, and practices that are specific to a good corporate governance has some determinant benefits such as an increased credibility of financial and non-financial reporting to the investors, the ease of access to capital and lower financing costs, the identification and valorization of all the competitive opportunities, the implementation of an adequate management control that ensures an efficient use of resources, and the adequate control of risks that could affect the sustainable development of the entities [1-4]. For this reason, the impact of corporate governance over financial performance has been questioned in different contexts. The basis of a good corporate governance is influenced by the management behavior, which plays a part in the accomplishment or non-accomplishment of the objectives of the entity [5-7]. In the given context, ensuring the quality of corporate governance imposes responsibility, correctness, transparency, and qualitative relationships among shareholders, board of directors, management, and employees [8-11]. In turn, these aspects define the authority and the responsibility of the ones that are part of the governance, by supplying sustainable value to all interested parties, as well as the basis for improving financial performance [12,13].

Due to its significant impact on the reporting of financial performance, it is meaningful to identify implementation solutions to ensure a pro-active approach in the field of risk management [14-16]. In ensuring information transparency, as required by an appropriate financial reporting system [17-20], it is necessary to adapt corporate governance practices to the particularities of each reporting entity.

Despite the fact that there are many initiatives to stimulate good corporate governance for economic growth, there are still gaps in developing countries. These can be caused by 
multiple factors, such as financial literacy [21], the level of savings [22], the level of corruption [23], or other external factors. However, most of the time, good corporate governance is a strategy conceived from within an entity, central to which are the board of directors and the management structure. In developing countries, corporate governance has become a widely discussed topic, being considered a key point for economic development [24-27]. Even though it is considered an important center of interest for in-depth economic and financial studies, we find that corporate governance mechanisms and practices are less developed in these countries [27]. Thus, the topic of corporate governance in developing or emerging market countries is still insufficiently debated in the literature, leaving an important gap that can be explored by conducting empirical or comparative studies. Our study highlights the importance of corporate governance mechanisms over financial performance in an emerging market from Europe.

Considering the increasing importance of corporate governance mechanisms and board structure, the aim of the paper is to identify the links between corporate governance practices and financial performance in 50 companies listed on the Bucharest Stock Exchange (BSE), a newly declared emerging market in the third trimester of 2020. As research conducted on a fresh emerging market, our contribution to the literature is notable and can mark a starting point for further research in order to observe the influence of this new status of the market on board composition, ownership, firm value, and performance. In the steps taken to achieve the purpose of this research, we acknowledge investors' interest in acquiring shares of entities with appropriate corporate governance frameworks as they tend to maintain or increase their share values. Additionally, of high relevancy is the investors' interest in analyzing the potential impact of distinctive corporate governance practices on overall performance, and particularly on financial performance.

In order to have a synoptic view of the relationship between the characteristics of corporate governance (especially the board of directors) and the financial performance of an entity, on the basis of the research conclusions provided by the literature, we synthesized the most important approaches and perspectives, and on this basis, formulated four hypotheses for this study.

The paper is structured as follows. Section 2 contains presentation of previous studies related to corporate governance and entity performance. Section 3 outlines the research methodology, and Section 4 presents the results and discussions regarding the specificity of entities' corporate governance practices and related aspects in conjunction with their performances and in Section 5 we concluded.

\section{Literature Review and Hypothesis Development}

The economic, social, and environmental challenges faced by societies determined the entities with an economic purpose to adopt measures and behaviors that would diminish the impact of the economic activity on these challenges. For this, the theory of legitimacy was developed in order to guide the process of disclosing economic, social, and environmental aspects [28]. These disclosures may affect the financial performance and value of the reporting entities.

Over time, many research and studies were carried, through which a series of relationships and contributions of corporate governance and sustainability were elucidated. The most relevant research focused on: the impact upon the increase of financial performance through the affiliation of entities to a group [29,30]; the adequate motivation and monitoring of managers with subsequent influence in share prices [31,32]; the determination of managers to apply investment policies that lead to the maximum value of the entities [33,34]; the increase of the performance and market value of entities [35-40]; the relationship between performance, structure, and stock holdings among the members of the board [41,42], and the increasing competition to attract investors and the economic performance of entities [43,44].

The relationship between good corporate governance and the financial performance of a corporation is a topic well studied, especially in the last 20 years, due to the notorious 
scandals of large corporations [45]. Big challenges, driven by the globalization phenomenon and change, lead to a rethinking of conceptualizing the responsibilities of an entity [46]. Over time, corporate governance systems have been affected by the vulnerabilities of internal control which caused failures to anticipate or notice the materialization of some risks, which include a loss of trust on behalf of investors in the business [47-49]. Relevant in this sense are the big financial scandals, which followed the bankruptcy of some big corporations such as Enron, WorldCom, Global Crossing, Arthur Andersen, and Parmalat. In the given circumstances, on an international, European, and national level, the authorities have taken some legislative and regulatory measures in order to create the necessary premises for re-building investors' confidence in the quality of financial and non-financial reports. One of these actions targets the enhancement of social performance through transparency and credibility in the image of the reporting entity. Eloquent proof is given by ensuring the correspondence between the actual financial performance and the represented reality. Besides the measures taken by authorities and professional organisms over time, a series of studies and research were undertaken that focused on the analysis of different dimensions of the relationship between corporate governance and global performance of an entity.

In the past decades, many researchers have been experimenting with new concepts, theories, or models to facilitate the understanding of the challenges of the business environment. One of the most notorious theories is the "stakeholder theory" [50] which suggests that stakeholder relationship analysis can lead to a better understanding of such challenges. Moreover, stakeholder interests are extremely important when considering the performance of an entity of its value. With reference to the analyzed factors and dimensions, the obtained results were different from a certain approached circumstance, situation, or stage to another. Hence, some studies highlighted the impact of the corporate governance mechanisms upon the quality of financial information, financial performance, share prices, or investment policies.

Corporate governance has been shown to increase transparency in financial reporting [51]. Multiple studies that examine the influence of corporate governance on financial performance [52-56] or the influence of compliance with corporate governance codes on financial performance-through the apply or explain principle [57-59] - show that the existence of corporate governance practices/mechanisms positively influence financial performance.

Moreover, the research on this topic has highlighted the diversity of the environments in which the entities function, a decisive factor that has stimulated the development of some corporate governance systems which are continuously evolving under legal, economic, financial, accounting and social points of view, including from one country to another [52].

According to both international and national financial reporting frameworks, the dedicated objective of financial reporting is the presentation of the financial position and financial performance, including cash flows and changes in equity. In this context, the financial performance is represented through accounting results, respectively, profit or loss and comprehensive income. In comparison with the profit or loss, determined as a difference between the total of revenues and expenses-out of which the components of other comprehensive income are excluded - the comprehensive income has a larger area that targets the modification of equity over a reporting period.

Achieving the global performance that could provide the foundation of a sustainable economic increase requires a complex approach of corporate governance, in which the identification of some adequate mechanisms for treating the risks generated by the divergent interests of the different interested parties is primordial $[60,61]$. Considering stakeholder and corporate governance perspectives, the board of directors is a key factor in increasing shareholder value, but also in protecting shareholders' interests. Thus, studying the board effectiveness has attracted a lot of research attention. A recent study analyzed the impact of board composition on sustainable performance on companies located in Tunisia. The results show that board effectiveness positively influences sustainability performance, 
expressed through economic, social and environmental performance [62]. Similar results were obtained by Chams and Garcia-Blandon [63] when analyzing a sample of 478 multinational companies. Additionally, gender diversity seems to increase sustainability disclosure and performance [64]. In contrast, a study on state-owned companies from Europe shows that board composition does not impact sustainability disclosure, but rather the industry in which it is activated [65].

Among the main responsibilities of the governance council, of particular relevance are the ones referring to management monitoring and guiding the entities towards financial and social performance through adequate strategies focused on value added. In the given context, in other studies it is shown that the most important element of corporate structures is the board of directors $(\mathrm{BoD})$. The structure of $\mathrm{BoD}$, the decision-making processes on which it is based, as well as the way in which its committees continuously improve corporate governance, have a major influence over the quality of the reported information. Moreover, establishing a corresponding vision at the highest organizational level of an entity is necessary for insuring a trustworthy climate [66].

The research carried on this topic has shown that in the structure of the BoD it is important to have a higher proportion of non-executive members compared to executive ones.

A non-executive or independent member of BoD is defined as a person who does not have executive responsibilities and who is not affiliated with the entity [56]. Theoretically, independent members are objective in the process of monitoring managers and thus ensure a better protection of the stakeholders' interests. The supporters of this theory have proven that a higher number of non-executive members improve the relationship between the investment opportunities of an entity and its performance [67-69].

In other studies, the existence of a positive relationship between non-executive members and entities' performance was demonstrated by improving the performance, the credit rating, the market value of the entity, and by other similar effects. Relevant to this is the research undertaken by O'Sullivan [70], who examined a sample of 402 British entities and concluded that the presence of non-executive members in $\mathrm{BoD}$ encourages internal audit which, in turn, contributes to the better monitoring of these structures of corporate governance. Additionally, under such circumstances the costs of agency are smaller. This conclusion was also reached by Fabrizi et al. [71] who proved that a higher proportion of independent members in $\mathrm{BoD}$ is correlated with a better performance of entities. On the contrary, the research carried by Weir and Laing [72] argued for a negative relationship between the representation of independent members and the performance of an entity. Previous research suggested that there was no correlation between the proportion of non-executive, independent members in the board of directors and the entity's financial results [42,67]. Moreover, based on the performed studies, Chang et al. [31] concluded that the interested parties are not satisfied by the way independent members represent their interests.

Based on the evidence obtained from the literature review, we formulated the following research hypothesis that targets the relationship between the independence of the $\mathrm{BoD}$ members and the performance of an entity:

Hypothesis 1. The number of independent members in the board of directors and the financial performance disclosed by an entity are positively correlated.

An essential characteristic of a BoD is the size of its structure. Some research has shown that entities with more directors can attract important resources in an easier manner and reduce the exposure to inherent risks [56]. Hence, in this type of situation, the coordination and the communication in the process of decision making is more difficult to accomplish, which in turn affects the way in which the objectives of an entity and the interested parties are achieved. By adding a new member to the $\mathrm{BoD}$, the relationship between diversity and coordination determines a potential opportunity cost. 
Some studies reached a conclusion that the optimal number of BoD members is between seven and eight. This recommendation depends on a series of factors specific to each entity, such as the industry in which the entity operates. Generally, credit institutions tend to have more BoD members than productive entities [67].

Previous research on this topic yielded different results concerning the impact that BoD size has on the performance of an entity. Hence, Lloret [73] identified a positive relationship between the BoD size and performance, while the results obtained by [74] are not conclusive.

Even though coordination is more difficult in the case of more BoD members, diversity, experience, and expertise for improving financial performance are supplied to the entities. Based on these arguments, in order to study the relationship between the BoD size and performance we formulated the following hypothesis:

Hypothesis 2. The financial performance disclosed by an entity and the size of its board of directors are positively correlated.

There are opinions that the conflicts between managers and shareholders are more easily overcome provided that the $\mathrm{BoD}$ members also have a role as shareholders in the considered entities. Moreover, the geographical and political aspects may determine the influence of corporate governance mechanism over financial performance or firm value. For example, many studies show big differences between European companies and U.S. companies. According to a study conducted by Lozano et al. [75], the ownership of European companies is highly concentrated, while the ownership of U.S. companies is more dispersed. The ownership structure can influence management decisions. In European companies, the main owner has effective control over the company's decision, thus trying to increase the firm value or the financial performance. We expect that the percent of the shares owned by BoD members is higher in European countries, like Romania. From this perspective, it is shown that if the BoD members are also shareholders, they are interested in the proper functioning of the entity, and are less motivated to behave negatively towards other shareholders [76]. Thus, conflicts between managers and shareholders can be decreased. On the contrary, other research showed that there was no correlation between the performance of an entity and the fact that the $\mathrm{BoD}$ members were also shareholders. Some other studies $[61,67,71]$ prove that when the BoD members are also shareholders, the entity's performance increases only by $5 \%$ after which it decreases, while the number of shares increases with $25 \%$ and re-increases slowly at higher levels of ownership. Moreover, the authors support the theory according to which managers tend to allocate resources to entities in their own interest. In the context of these theories, the hypothesis regarding the connection or relationship between the BoD members as shareholders of an entity and performance is:

Hypothesis 3. The quality of shareholders among the members of the board of directors and the financial performance disclosed by an entity are positively correlated.

As in the case of the other variables, there are several approaches to the relationships that exist between the BoD chairman-CEO duality and the performance of an entity. The $\mathrm{CEO}$ is the person that provides the top management of an entity. Many researchers have concluded that a combination of the BoD Chairman and CEO positions is not optimal for the leadership structure of an entity. This perspective shows that through the concentration of the decision authority, independence is limited and efficiency in monitoring management is reduced $[36,49,77,78]$. Moreover, a study conducted by Chen et al. [79] shows that the duality of the $\mathrm{CEO} /$ chairman does not cause financial distress.

Other research showed no significant relationship from this perspective. Moreover, it was highlighted that under the circumstance of one person holding two positions, the entity will have a unitary and stronger leadership. Moreover, the elimination of the potential CEO-BoD chairman conflict will help avoid the confusion generated when an entity is 
publicly represented by two persons that could have different perspectives $[67,70]$. Based on previous research, we aim to test the following hypothesis:

Hypothesis 4. Independent membership of the Chairman of the Board of Directors and financial performance disclosed by an entity are positively correlated.

Our empirical analysis is based on studying the correlation between different aspects of the board of directors and financial performance, as illustrated in Figure 1.

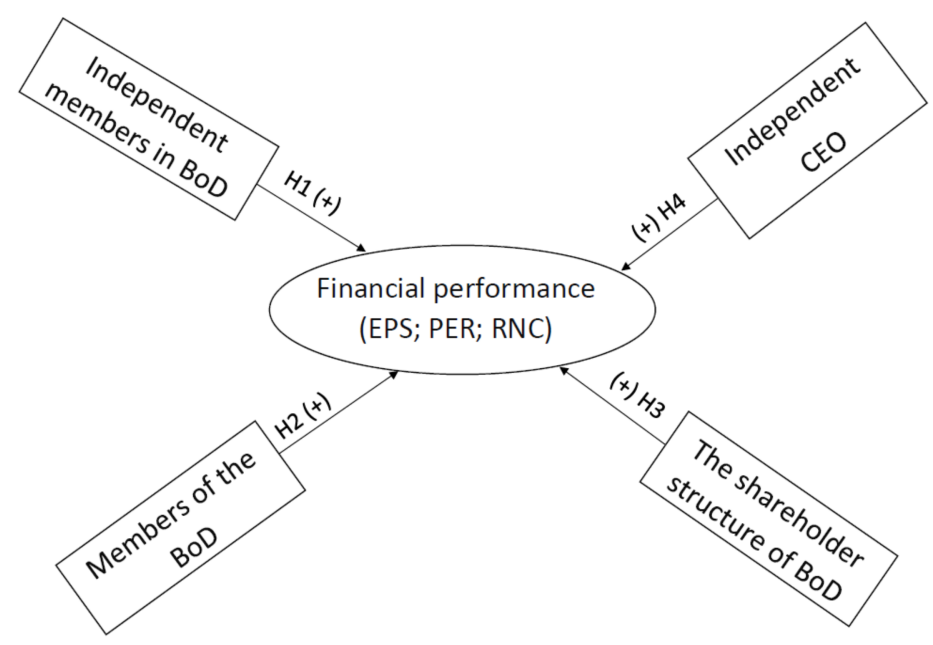

Figure 1. Hypothesis development.

\section{Research Methodology}

In approaching the theories regarding corporate governance, under the circumstances of divergent interests on behalf of the interested parties, transparency and utility of information, we used a deductive approach to test the relationship between corporate governance and financial performance.

Within the empirical research, through an inductive approach, we noticed some relationships of dependency and causality that exist between some of the characteristics regarding leadership and compliance and the performance of the listed entities.

In the national context, corporate governance has gained importance in the last decades. The Bucharest Stock Exchange elaborated a Corporate Governance Code (hereinafter referred as CGC) imposed to companies listed on the Main Segment, Premium, and Standard tiers. Over time, this CGC was updated and today it incorporates 41 requirements for Premium tier listed companies and 40 requirements for Standard tier listed companies, which are structured into four main sections: Section A-Responsibilities of the Board of Directors; Section B-Internal Control and Risk Management; Section C-Reward and Motivation; Section D-Value Added through Relationship with Investors [80]. Thus, in respect to board composition and their role in the governance of a company, all analyzed companies must comply with CGC through the apply or explain principle, but they also must report data regarding board composition and structure.

In approaching the relationship between financial performance and the management system of an entity, financial information has a primordial role [81]. Considering the corporate governing of the listed entities, the financial-accounting systems offer direct information about the mechanisms of corporate control and indirect output to the external factors that impact the considered entities. In practice, the obtained results are not always very conclusive, considering that they are affected by the materialization of the distortion risk or by the informational asymmetries. Usually, these are highlighted through the means of the financial and non-financial indicators, which are constructed in different circumstances. 
Based on aspects regarding the structure, size, and share ownership by the BoD members, which have been approached in the research carried on this topic by Lozano [82] and Ullah [36], we extrapolated and extended these elements over the BVB listed entities, in order to investigate the impact of the BoD's characteristics over financial performance.

We also took into account the fact that in the corporate governance code applicable to these entities, the necessity of information transparency according with the represented economic reality was highlighted.

Financial performance is expressed through the following dependent variables: Net Accounting Result (RNC), Price Earnings Ratio (PER) and Earnings per Share (EPS).

RNC was collected from the published financial statements, and PER and EPS from the statistics published by BVB. Our analysis was conducted for the year 2019.

PER and EPS were determined as:

$$
\begin{aligned}
& \text { PER }=\text { SP } / \text { PRS } \\
& \text { EPS }=\mathrm{NP} / \mathrm{NS}
\end{aligned}
$$

where:

SP-Share price; PRS- Profit per share; NP- Net Profit; NS- Number of shares.

The econometric model is composed of three equations of linear regression (OLS):

$$
\begin{aligned}
& \mathrm{RNC}=\mathrm{A}+\mathrm{a} 1 \mathrm{SCA}+\mathrm{a} 2 \mathrm{MCA}+\mathrm{a} 3 \mathrm{ACA}+\mathrm{a} 4 \mathrm{CEO}+\varepsilon \\
& \mathrm{PER}=\mathrm{B}+\mathrm{b} 1 \mathrm{SCA}+\mathrm{b} 2 \mathrm{MCA}+\mathrm{b} 3 \mathrm{ACA}+\mathrm{b} 4 \mathrm{CEO}+\varepsilon \\
& \mathrm{EPS}=\mathrm{C}+\mathrm{c} 1 \mathrm{SCA}+\mathrm{c} 2 \mathrm{MCA}+\mathrm{c} 3 \mathrm{ACA}+\mathrm{c} 4 \mathrm{CEO}+\varepsilon
\end{aligned}
$$

where:

A, B, C-the values of the financial performance when the independent variables are $0 ; a, b, c, 1-4$ - the coefficients that describe the size of the effects of the independent variables over the dependent one; RNC-Net Accounting Result; PER-Price Earnings Ratio; EPS—Earnings per Share; SCA — The BoD structure; MCA-The BoD size; ACA—the shareholder' structure of BoD; CEO — the duality of the role CEO-BoD Chairman; $\varepsilon$ - the error of the model.

The independent variables are represented by the BoD structure, the BoD size, the shareholder quality of the BoD members, the duality of the role of CEO and the BoD chairman. The independent variables were measured in the following manner: the BoD structure - the proportion of non-executive members in the total of BoD members; the BoD size-the number of BoD members; the quality of shareholder of the BoD members-the proportion of the number of BoD members who own shares; the duality of the role of BoD Chairman and CEO-" 0 " for the case in which the roles are held by the same person and "1" for the situation in which the functions are held by different persons.

Based on the epistemological hypotheses, we performed a quantitative analysis of a sample formed from 50 entities that are listed on the Bucharest Stock Exchange (BVB) in Romania [70]. These were selected according to the following criteria: operate in a different industry than financial, banking and insurance; listed on the regulated stock exchange market; have financial and corporate governance information published on the website; adopt the one-tier corporate governance model.

The analyses of the association, correlations, and relations between the proposed variables were achieved through the SPSS program.

\section{Results and Discussions}

The values of the Pearson coefficients reflect the correlations that exist between the dependent variables and the independent ones, as well as the level of significance.

The results obtained regarding the correlation relationships among RNC, PER, and EPS, and BoD characteristics for the entities listed on the Bucharest Stock Exchange Romania [83] are presented in Table 1. 
Table 1. The correlation relationships between performance (RNC, PER, and EPS) and the BoD characteristics for entities listed on the Bucharest Stock Exchange (Source: own processing using SPSS software).

\begin{tabular}{ccccccc}
\hline Variable & Test Results & SCA & MCA & ACA & CEO & RNC \\
\hline \multirow{3}{*}{ RNC } & Pearson Correlation & 0.09 & $0.305^{* *}$ & -0.069 & $0.189^{*}$ & 1 \\
& Sig. (2-tailed) & 0.227 & 0 & 0.358 & 0.011 & \\
& N & 50 & 50 & 50 & 50 & \\
\hline \multirow{2}{*}{ PER } & Pearson Correlation & 0.017 & $-0.198^{* *}$ & -0.104 & -0.107 & 1 \\
& Sig. (2-tailed) & 0.835 & 0.015 & 0.203 & 0.192 & \\
& N & 50 & 50 & 50 & 50 & \\
\hline \multirow{2}{*}{ EPS } & Pearson Correlation & -0.114 & -0.057 & 0.014 & 0.119 & 1 \\
& Sig. (2-tailed) & 0.211 & 0.328 & 0.879 & 0.19 & \\
& $N$ & 50 & 50 & 50 & 50 &
\end{tabular}

1 Pearson Correlation-correlation coefficient; Sig. (2-tailed)—significant level; $\mathrm{N}$-number of entries; **-significant at $0.01 ; *$ - significant at 0.05 .

Table 2 presents a summary of the determined econometrics model- $\mathrm{R}$ square, parameter which indicates the explicative power of the independent variables.

Table 2. BoD characteristics for the entities listed on hte Bucharest Stock Exchange: the summary of the RNC, PER, EPS (Source: own processing using SPSS software).

\begin{tabular}{ccccc}
\hline Model & R & R Square & Adjusted R Square & Std. Error of the Estimate \\
\hline RNC & $0.344 a$ & 0.118 & 0.098 & 94.25689684 \\
PER & $0.244 a$ & 0.059 & 0.034 & 51.85434575 \\
EPS & $0.264 a$ & 0.070 & 0.030 & 1.66697448 \\
\hline
\end{tabular}

As shown in Table 2, R square in the case of RNC is 0.118 , which shows that $11.8 \%$ of the variation of the financial performance is influenced by the variation of the analyzed independent variables. For the other dependent variables, $\mathrm{R}$ square is smaller, 0.059 for PER and 0.07 for EPS. It could be noticed that, in the model with the RNC as dependent variable, the independent variables have the highest exploratory power or influence over financial performance.

Through econometric analysis computation (multiple OLS), we tested our research hypotheses. Synthetically, the obtained results for the three dependent variables are presented in Table 3.

Table 3. Linear regression testing for hypotheses validation on the sample of the entities listed on the Bucharest Stock Exchange (Source: own processing using SPSS software).

\begin{tabular}{cccc}
\hline Model $^{\mathbf{1}}$ & RNC & PER & EPS \\
\hline Intercept & -73.241 & 45.9808 & 0.391 \\
SCA & 0.091 & 0.030 & $-0.225^{*}$ \\
MCA & $0.297^{* *}$ & $-0.178^{*}$ & 0.132 \\
ACA & -0.047 & -0.102 & 0.032 \\
CEO & 0.087 & -0.122 & $0.216^{*}$ \\
\hline
\end{tabular}

1**-significant at $0.01 ;{ }^{*}$ —significant at 0.05 .

In a more fashionable way, we can present the following value profiles of the listed entities:

$$
\begin{gathered}
\text { RNC }=-73.241+0.091 \mathrm{SCA}+0.297 \mathrm{MCA}+(-0.047) \mathrm{ACA}+0.087 \mathrm{CEO} \\
\mathrm{PER}=45.9808+0.030 \mathrm{SCA}+(-0.178) \mathrm{MCA}+(-0.102) \mathrm{ACA}+(-0.122) \mathrm{CEO} \\
\mathrm{EPS}=0.391+(-0.225) \mathrm{SCA}+0.132 \mathrm{MCA}+0.032 \mathrm{ACA}+0.216 \mathrm{CEO}
\end{gathered}
$$


Starting from the assumption that independent BoD members have the ability to adequately limit and control the agency's problems, reflected through the opportunistic management behavior, the first research hypothesis brought into attention the fact that a higher proportion of non-executive BoD members leads to a more efficient monitoring of management. The correspondence between the $\mathrm{BoD}$ structure and the value of the three indicators through which the financial performance is represented are different. According to the results of the regression models, namely the values reflected by the Pearson coefficients, we find a positive correlation at the level of 0.09 between SCA and RNC and 0.017 between SCA and PER. In case of the linear regression, RNC and PER have a positive correlation with SCA. Thus, if the proportion of independent members increases, performance also increases, as several studies also found $[36,49,68,84]$. However, these findings are not statistically significant. Between SCA and EPS, there is a negative and significant correlation. This finding is in line with the related literature, as Udiale [67] and Hategan et al. [42] found in their study. According to our results, H1 is rejected.

Based on the values recorded following our research, we find a positive correlation between RNC and MCA, which is $30.5 \%$ statistically significant. Thus, $30.5 \%$ of the fluctuation in financial performance is caused by the change in the number of board members. Since the coefficient a2 (0.297) is statistically significant, the proposed hypothesis is validated, and the correlation is positive. A larger board of directors, due to the diversity of opinions, means better governance, which is reflected in the financial performance expressed through RNC of the entities considered. Our results are similar to other related research, which considered return on equity (ROE) or return on assets (ROA) as financial performance indicators $[49,71]$.

Considering the Pearson coefficient, the correlation between PER, EPS, and MCA is negative. Relative to the regression function, results are not conclusive. On one side, the relationship between PER and MCA is negative and statistically significant, and on the other side, the one between EPS and MCA is positive, but statistically insignificant. These results are similar to those obtained by Bebchuk and Weisbach [74].

The third hypothesis refers to the relationship between financial performance and owning shares by the BoD members in the analyzed entities. Hence, the research focused on testing the hypothesis that owning shares by the BoD members could help reduce agency costs and optimize the decision-making process, aspects that have positive effects on performance. According to the performed analyses, we noticed a negative relationship between RNC, PER, and ACA and a positive one between EPS and ACA. Through the application of the linear regression function, the relationship between the $\mathrm{BoD}$ members who also own shares in the entity and RNC and PER has a negative result, while with EPS a positive one. However, it is important to mention that the results are not statistically significant. Thus, we reject $\mathrm{H} 3$.

A part of the previous research has shown that $\mathrm{BoD}$ is inefficient when the chairman and the $\mathrm{CEO}$ are the same person. In this situation, leadership decisions cannot be adequately controlled since the chairman is put in the position to monitor and control his/her own decisions, which may not be in the best interests of the shareholders. In this context, the performance of an entity could be negatively affected. From the analysis of the statistical results, we established a positive correlation between RNC, EPS, and CEO, and a negative one between PER and CEO. The correlation between RNC and CEO is statistically significant, and thus we could state that $18.9 \%$ of the RNC variation results from the changes of the CEO. Similar with the analysis of the Pearson R coefficient, by applying the function of linear regression, the same correlations resulted. However, in this case the relationship between EPS and CEO is statistically significant. Hence, hypothesis $\mathrm{H} 4$ was validated through the dependent variable EPS. When the roles of $\mathrm{BoD}$ chairman and of CEO are held by different persons, EPS increases by $21.6 \%$. These results show that the duality of the chairman affect the firm's value, as previous research has proven $[67,85]$. 


\section{Conclusions}

A good corporate governance relies on the existence of some trust relationships between the entity, the investors, and other interested parties.

The obtained results are divergent in terms of the analyzed dependent and independent variables and the formulated hypotheses. Two of the formulated hypotheses have been confirmed, namely hypothesis $\mathrm{H} 2$, according to which there is a positive relationship between MCA and the financial performance (RNC) and hypothesis $\mathrm{H} 4$, according to which there is a positive correlation between the independence of BoD chairman and CEO positions and the financial performance (EPS).

Based on our results, there are two statistically significant correlations, but their meaning is divergent from the proposed assumptions. On one side, MCA has a negative correlation with PER, a result that is opposed to the one between the BoD size and RNC. In the given circumstances, these differences could be explained by the fact that MCA depends on a series of factors, among which are the entity's dimension, the industry in which it operates, the market value, and the maturity level of the stock exchange market. On the other side, SCA has a negative correlation with EPS, which could be owed to the lack of experience of the non-executive members compared to the executive members that know the entity better and could take better documented decisions.

Validating hypothesis H4 reconfirms the hypothesis from Uadiale's research [67], which shows that for the entities that are in a development process, financial performance is better when the roles of the $\mathrm{BoD}$ chairman and CEO are held by different persons.

To conclude, by ensuring some balanced structures of corporate governance that are highlighted through the validation of $\mathrm{H} 2$ and $\mathrm{H} 4$ hypotheses, entities have a better financial performance, an aspect that is confirmed in the accounting information supplied by the financial statements to the different interested parties. Essentially, confirming these relationships helps to elucidate the value profiles of the listed entities and offers solutions to enhance the performance presented in the financial statements.

The results of this research show the valences of the corporate governance structure in an entity and implicitly within the entire financial reporting process, as also reported in other research studies by Gino [84], Hategan et al. [42], and Danescu et al. [13].

Our results are similar to those of other authors mentioned in this paper. Moreover, the effectiveness of CGC requirements is empirically proven by our results, thus contributing to the development of the literature. The main results can have practical implications, as they provide empirical guidance on which board characteristics influence financial performance expressed through EPS, PER, and RNC. Our main findings highlight that EPS is generally positively influenced by the board composition, while RNC is positively influenced by board size. These results can guide management representants for further in-depth analyses of their internal position and policy or strategy development and implementation.

The conclusion regarding the role of corporate governance in creating added value and in recognizing its contribution for increasing financial performance is indisputable. Additionally, it highlights the specificity of policies, practices, and corporate identity elements that define the image of an entity within the economy or market that it operates in. Our results offer an insightful into how corporate governance influences financial and sustainable corporate performance in an emerging market in the European Union.

Moreover, as a new market status, foreign investments are promising, and regulators have the obligation to ensure the smooth running of operations on this market. Thus, this new emerging market opens a research universe for academics, who must provide viable, credible, transparent, and intelligible answers to both authorities and investors and the general public. Thus, future research on this market is imminent and could help regulators improve and develop new strategies to accelerate sustainable economic growth.

Further on, a research study on the role of corporate governance in the financial reporting process can be developed, namely on the influence that corporate managers' statements within published reports have on improving stakeholders' relations. Moreover, independent variables that enhance sustainability could be added to the model. 
The inherent limits of the carried research are represented by the relativity of the dependent variables (RNC, PER, EPS) highlighted by the inconveniences of the financial reporting process, namely the information supplied by the financial statements that are used as support. Thus, in future research, it is important to take into account other dependent variables, such as the extension of the research for entities that operate on stock exchange markets with different levels of maturity.

Author Contributions: All authors contributed equally to this work. Conceptualization, T.D., I.-O.S. and M.-A.P.; methodology, I.-O.S. and C.-G.S.; software, C.-G.S.; validation, T.D. and M.-A.P.; formal analysis, I.-O.S. and C.-G.S.; investigation, I.-O.S.; resources, M.-A.P.; data curation, C.-G.S.; writingoriginal draft preparation, T.D., C.-G.S. and I.-O.S.; writing-review and editing, M.-A.P. and I.-O.S.; visualization, M.-A.P. and T.D.; supervision, T.D.; project administration, T.D.; funding acquisition, M.-A.P. and C.-G.S. All authors have read and agreed to the published version of the manuscript.

Funding: This work was supported by the University of Medicine, Pharmacy, Science and Technology “George Emil Palade” of Targu Mures, Research Grant number 10128/17.12.2020.

Data Availability Statement: Data can be provided upon reasonable request.

Acknowledgments: The authors would like to thank the editor and the three reviewers for the insightful comments for improving our manuscript. The authors also thank Roxana Diana Prozan for her constant feedback and help in building our research paper and for the English proofreading.

Conflicts of Interest: The authors declare no conflict of interest.

\section{References}

1. Ashkanasy, N.M.; Windsor, C.A. Personal and Organisational Factors Affecting Auditor Independence: Empirical Evidence and Directions for Future Research. Res. Account. Ethics 1997, 3, 35-48.

2. Black, B.; Jang, H.; Kim, W. Does corporate governance predict firms' market values? Evidence from the Korean market. J. Law Econ. Organ. 2016, 22, 366-413. [CrossRef]

3. Herdjiono, I.; Sari, I.M. The Effect of Corporate Governance on the Performance of a Company. Some Empirical Findings from Indonesia. J. Manag. Bus. Adm. 2017, 25, 33-52. [CrossRef]

4. Oncioiu, I.; Căpuşneanu, S.; Türkeș, M.C.; Topor, D.I.; Constantin, D.-M.O.; Marin-Pantelescu, A.; Hint, M.S. The Sustainability of Romanian SMEs and Their Involvement in the Circular Economy. Sustainability 2018, 10, 2761. [CrossRef]

5. Ponemon, L.A. The Objectivity of Accountants' Litigation Support Judgements. Account. Rev. 1995, 70, 467-488.

6. Bertschinger, P.; Schaad, M. Der amerikanische Sabanes-Oxley Act of 2002-Mögliche Auswirkungen auf die amerikanische und international Wirtschaftsprüfung und Corporate Governance. Der. Schweiz. Treuhänder. 2003, 10, 883-888.

7. Zakaria, A. The Influence of the Audit Committee and the Remuneration Committee on Company Performance. In Proceedings of the International Conference on Islamic Finance, Economics and Business (ICIFEB), Tangerang, Indonesia, 11-12 October 2017; Supriyono, M.M., Ed.; KnE Social Sciences: Dubai, United Arab Emirates, 2018; pp. 18-32.

8. Choi, K.S.; Cho, W.H.; Lee, S.H.; Lee, H.J.; Kim, C.K. The Relationships among Quality, Value, Satisfaction and Behavioral Intention in Health Care Provider Choice: A South Korean Study. J. Bus. Res. 2004, 57, 913-921. [CrossRef]

9. Carcello, J.V.; Neal, T.L.; Zoe-Vonna, P.; Scholz, S. CEO Involvement in Selecting Board Members and Audit Committee Effectiveness. 2008. Available online: http:/ / www.ssrn.com/abstract=887512 (accessed on 22 October 2018).

10. Fülöp, M.T. Audit in Corporate Governance; Alma Mater Publishing House: Cluj-Napoca, Romania, 2012.

11. Dănescu, T.; Popa, M.A. Public health and corporate social responsibility: Exploratory study on pharmaceutical companies in an emerging market. Glob. Health 2020, 16, 117. [CrossRef] [PubMed]

12. Collier, P.; Zaman, M. Convergence in European corporate governance: The audit committee concept. Corp. Gov. 2005, 13, 753-768. [CrossRef]

13. Dănescu, T.; Prozan, M.; Prozan, R.D. Perspectives regarding accounting—corporate governance-Internal control. Proc. Econ. Financ. 2015, 32, 588-594. [CrossRef]

14. Anderson, R.C.; Mansi, S.A.; Reeb, D.M. Board characteristics, accounting report integrity and the cost of debt. J. Account. Econ. 2004, 37, 315-342. [CrossRef]

15. Beiner, S.; Schmid, M.M.; Drobetz, W.; Zimmermann, H. An Integrated Framework of Corporate Governance and Firm Valuation. Eur. Financ. Manag. 2006, 12, 249-283. [CrossRef]

16. Sewell, M. Behavioral Finance; University of Cambridge: Cambridge, UK, 2010.

17. Vafeas, N. Board meeting and firm performance. J. Financ. Econ. 1999, 53, 113-142. [CrossRef]

18. Song, J.; Windram, B. Benchmarking audit committee effectiveness in financial reporting. Int. J. Audit. 2004, 8, 195-205. [CrossRef]

19. Danquah, B.S.; Gyimah, P.; Afriyie, R.O.; Asiamah, A. Corporate Governance and Firm Performance: An Empirical Analysis of Manufacturing Listed Firms in Ghana. Account. Financ. Res. 2017, 7, 111-118. [CrossRef] 
20. Fernandes, D.; Lynch, J.G.; Netemeyer, R.G. Financial Literacy, Financial Education, and Downstream Financial Behaviors. Manag. Sci. 2014, 60, 1861-1883. [CrossRef]

21. Salahuddin, M.; Islam, M.R. Factors Affecting Investment in Developing Countries: A Panel Data Study. J. Dev. Areas 2008, 42, 21-37. [CrossRef]

22. Bolgorian, M. Corruption and stock market development: A quantitative approach. Phys. A Stat. Mech. Appl. 2011, 390, 4514-4521. [CrossRef]

23. Black, B.S.; Khanna, V.S. Can corporate governance reforms increase firm market values? event study evidence from india. J. Empir. Leg. Stud. 2007, 4, 749-796. [CrossRef]

24. Claessens, S. Corporate Governance and Development. World Bank Res. Obs. 2006, 21, 91-122. [CrossRef]

25. Allen, F. Corporate Governance in Emerging Economies. Oxf. Rev. Econ. Policy 2005, 21, 164-177. [CrossRef]

26. Clarke, T. International Corporate Governance: A Comparative Approach, 2nd ed.; Routledge: Oxfordshire, UK, 2017. [CrossRef]

27. Claessens, S.; Yurtoglu, B.B. Corporate Governance and Development: An Update; Global Corporate Governance Network, IFC.: London, UK, 2012. Available online: https: / / ssrn.com/abstract=2061562 (accessed on 23 August 2021).

28. Burlea, A.S.; Popa, I. Legitimacy Theory. Encycl. Corp. Soc. Responsib. 2013, 20, 1579-1584. [CrossRef]

29. Shi, H.; Zhang, X.; Zhou, J. Cross-listing and CSR performance: Evidence from AH shares. Front. Bus. Res. China 2018, $12,11$. [CrossRef]

30. Ball, R.; Kothari, S.; Robin, A. The effect of international institutional factors on properties of accounting earnings. J. Account. Econ. 2000, 29, 1-51. [CrossRef]

31. Chang, C.-S.; Yu, S.-W.; Hung, C.-H. Firm risk and performance: The role of corporate governance. Rev. Manag. Sci. 2014, 9, 141-173. [CrossRef]

32. Bushman, R.M.; Smith, A.J. Financial accounting information and corporate governance. J. Account. Econ. 2001, 32, 237-333. [CrossRef]

33. Crişan-Mitra, C.; Borza, A. Approaching CSR in Romania: An Empirical Analysis. Procedia Soc. Behav. Sci. 2015, 207, 546-552. [CrossRef]

34. Klapper, L.F.; Love, I. Corporate Guvernance Investor Protection, and Performance in Emerging Markets. J. Corp. Financ. 2004, 10, 287-322. [CrossRef]

35. Black, B.S.; Love, I.; Rachinsky, A. Corporate governance indices and firms' market values: Time series evidence from Russia. Emerg. Mark. Rev. 2006, 7, 361-379. [CrossRef]

36. Ullah, W. Evolving corporate governance and firms performance: Evidence from Japanese firms. Econ. Gov. 2016, 18, 1-33. [CrossRef]

37. Mishra, A.K.; Jain, S.; Manogna, R.L. Does corporate governance characteristics influence firm performance in India? Empirical evidence using dynamic panel data analysis. Int. J. Discl. Gov. 2020, 18, 71-82. [CrossRef]

38. Rehman, M.A.; Shah, S.G.M.; Cioca, L.-I.; Artene, A. Accentuating the Impacts of Political News on the Stock Price, Working Capital and Performance: An Empirical Review of Emerging Economy. J. Econ. Forecast. 2021, 24, 55.

39. Abidin, Z.Z.; Kamal, N.M.; Jusoff, K. Board Structure and Corporate Performance in Malaysia. Int. J. Econ. Financ. 2009, 1, 150-164. [CrossRef]

40. Pucheta-Martínez, M.C.; Fuentes, C. The impact of audit committee characteristics on the enhancement of the quality of financial reporting: An empirical study in the Spanish context. Corp. Gov. 2007, 15, 1394-1412. [CrossRef]

41. Drobetz, W.; Schillhofer, A.; Zimmermann, H. Corporate Governance and Firm Performance: Evidence from Germany; Working Paper. 2004. Available online: http://pages.unibas.ch/wwz/finanz/publications/researchpapers/10-03\%20CorpGov.pdf (accessed on 24 October 2018).

42. Hategan, C.-D.; Sirghi, N.; Curea-Pitorac, R.-I.; Hategan, V.-P. Doing Well or Doing Good: The Relationship between Corporate Social Responsibility and Profit in Romanian Companies. Sustainability 2018, 10, 1041. [CrossRef]

43. Grove, H.; Basilico, E. Major Financial Reporting Frauds of the 21st Century: Corporate Governance and Risk Lessons Learned. J. Forensic Investig. Account. 2011, 3, 36. Available online: https://ssrn.com/abstract=2277524 (accessed on 23 August 2021).

44. Vintila, G.; Paunescu, R.A. Empirical Analysis of the Connection between Financial Performance and Corporate Governance within Technology Companies Listed on NASDAQ Stock Exchange. J. Financ. Stud. Res. 2016, 2016, 1-20. [CrossRef]

45. Finegold, D.; Benson, G.S.; Hecht, D. Corporate Boards and Company Performance: Review of research in light of recent reforms. Corp. Gov. Int. Rev. 2007, 15, 865-878. [CrossRef]

46. Parmar, B.L.; Freeman, R.E.; Harrison, J.S.; Wicks, A.C.; Purnell, L.; de Colle, S. Stakeholder Theory:The State of the Art. Acad. Manag. Ann. 2010, 4, 403-445. [CrossRef]

47. Gușe, R.G.; Almășan, A.; Circa, C.; Dumitru, M. The role of the stakeholders in the institutionalization of the CSR reporting in Romania. Account. Manag. Inf. Syst. 2016, 15, 304.

48. Armstrong, C.S.; Guay, W.R.; Weber, J.P. The role of information and financial reporting in corporate governance and debt contracting. J. Account. Econ. 2010, 50, 179-234. [CrossRef]

49. Ahmad, I.; Sadiqa, B.A.; Khan, R. The Impact of Corporate Governance Practices on the Firm Financial Performance of the Non-Financial Firms. Glob. Econ. Rev. 2021, 6, 53-70. [CrossRef]

50. Freeman, R.E. Strategic Management: A Stakeholder Approach; Cambridge University Press: Cambridge, UK, 2010. 
51. Paniagua, J.; Rivelles, R.; Sapena, J. Corporate governance and financial performance: The role of ownership and board structure. J. Bus. Res. 2018, 89, 229-234. [CrossRef]

52. Kao, M.-F.; Hodgkinson, L.; Jaafar, A. Ownership structure, board of directors and firm performance: Evidence from Taiwan. Corp. Gov. Int. J. Bus. Soc. 2019, 19, 189-216. [CrossRef]

53. Alahdal, W.; Alsamhi, M.H.; Tabash, M.I.; Farhan, N.H. The impact of corporate governance on financial performance of Indian and GCC listed firms: An empirical investigation. Res. Int. Bus. Financ. 2019, 51, 101083. [CrossRef]

54. Peizhi, W.; Ramzan, M. Do corporate governance structure and capital structure matter for the performance of the firms? An empirical testing with the contemplation of outliers. PLoS ONE 2020, 15, e0229157. [CrossRef]

55. Albu, C.N.; Girbina, M.M. Compliance with corporate governance codes in emerging economies. How do Romanian listed companies "comply-or-explain"? Corp. Gov. Int. J. Bus. Soc. 2015, 15, 85-107. [CrossRef]

56. Rose, C. Firm performance and comply or explain disclosure in corporate governance. Eur. Manag. J. 2016, 34, 202-222. [CrossRef]

57. Aluchna, M.; Kuszewski, T. Does Corporate Governance Compliance Increase Company Value? Evidence from the Best Practice of the Board. J. Risk Financ. Manag. 2020, 13, 242. [CrossRef]

58. Siminica, M.; Cristea, M.; Sichigea, M.; Noja, G.G.; Anghel, I. Well-Governed Sustainability and Financial Performance: A New Integrative Approach. Sustainability 2019, 11, 4562. [CrossRef]

59. Mwambuli, E.L. The Effects of Board Structure Characteristics on Corporate Financial Performance in Developing Economies: Evidence from East African Stock Markets. Eur. J. Bus. Manag. 2016, 8, 126-138.

60. Villarón-Peramato, O.; Martinez-Ferrero, J.; Garcia-Sanchez, I.-M. CSR as entrenchment strategy and capital structure: Corporate governance and investor protection as complementary and substitutive factors. Rev. Manag. Sci. 2016, 12, 27-64. [CrossRef]

61. Chiang, H.T.; He, L.J. Board supervision capability and information transparency. Corp. Gov. 2010, 18, 18-31. [CrossRef]

62. Kouaib, A.; Mhiri, S.; Jarboui, A. Board of directors' effectiveness and sustainable performance: The triple bottom line. J. High. Technol. Manag. Res. 2020, 31, 100390. [CrossRef]

63. Chams, N.; García-Blandón, J. Sustainable or not sustainable? The role of the board of directors. J. Clean. Prod. 2019, 226, 1067-1081. [CrossRef]

64. Martínez, M.D.C.V.; Rambaud, S.C.; Oller, I.M.P. Gender policies on board of directors and sustainable development. Corp. Soc. Responsib. Environ. Manag. 2019, 26, 1539-1553. [CrossRef]

65. Nicolo', G.; Zanellato, G.; Manes-Rossi, F.; Tiron-Tudor, A. Beyond Financial Reporting. Integrated Reporting and its determinants: Evidence from the context of European state-owned enterprises. Financ. Rep. 2019, 72, 43-72. [CrossRef]

66. Rathnayake, D.N.; Sun, G. Corporate Ownership, Governance and Performance: Evidence form Asian Countries. Res. J. Financ. Account. 2017, 8, 28-36.

67. Uadiale, O. Impact of Board Structure on Performance in Nigeria. Int. J. Bus. Manag. 2010, 5, $155-166$.

68. An, Z.; Li, D.; Yu, J. Earnings management, capital structure, and the role of institutional environments. J. Bank. Financ. 2016, 68, 131-152. [CrossRef]

69. Beasley, M.; Carcello, J.; Hermanson, D.; Lapides, P.D. Fraudulent Financial Reporting: Consideration of Industry Traits and Corporate Governance Mechanisms. Account. Horiz. 2000, 14, 441-454. [CrossRef]

70. O'Sullivan, N. The impact of board composition and ownership on audit quality: Evidence from large UK companies. Br. Account. Rev. 2000, 32, 397-414. [CrossRef]

71. Fabrizi, M.; Mallin, C.; Michelon, G. The Role of CEO's Personal Incentives in Driving Corporate Social Responsibility. J. Bus. Ethic. 2013, 124, 311-326. [CrossRef]

72. Weir, C.; Laing, D. The Performance-Governance Relationship: The Effects of Cadbury Compliance on UK Quoted Companies. J. Manag. Gov. 2000, 4, 265-281. [CrossRef]

73. Lloret, A. Modeling corporate sustainability strategy. J. Bus. Res. 2016, 69, 418-425. [CrossRef]

74. Bebchuk, L.A.; Weisbach, M.S. The State of Corporate Governance Research. Rev. Financ. Stud. 2010, 23, 939-961. [CrossRef]

75. Lozano, M.B.; Martínez, B.; Pindado, J. Corporate governance, ownership and firm value: Drivers of ownership as a good corporate governance mechanism. Int. Bus. Rev. 2016, 25, 1333-1343. [CrossRef]

76. Tiron-Tudor, A.; Hurghis, R.; Lacurezeanu, R.; Podoaba, L. The Level of European Companies' Integrated Reports Alignment to the Framework: The Role of Boards' Characteristics. Sustainability 2020, 12, 8777. [CrossRef]

77. Claessens, S.; Yurtoglu, B.B. Corporate governance in emerging markets: A survey. Emerg. Mark. Rev. 2013, 15, 1-33. [CrossRef]

78. Akbar, A. The Role of Corporate Governance Mechanism in Optimizing Firm Performance: A Conceptual Model for Corporate Sector of Pakistan. J. Asian Bus. Strategy 2015, 5, 109-115.

79. Chen, C.-C.; Chen, C.-D.; Lien, D. Financial Distress Prediction Model: The Effects of Corporate Governance Indicators. J. Forecast. 2020, 39, 1238-1252. [CrossRef]

80. Bucharest Stock Exchange. Corporate Governance Code. 2015. Available online: https://www.bvb.ro/info/Rapoarte/Diverse/ RO_Cod\%20Guvernanta\%20Corporativa_WEB_revised.pdf. (accessed on 16 September 2021).

81. Baltes-Götz, B. Lineare Regressions Analyse Mit SPSS. Available online: http://www.uni-trier.de/urt/user/baltes/docs/linreg/ linreg.pdf. (accessed on 27 October 2020).

82. Lozano, R. A Holistic Perspective on Corporate Sustainability Drivers. Corp. Soc. Responsib. Environ. Manag. 2013, 22, 32-44. [CrossRef] 
83. Bucharest Stock Exchange. 2018. Available online: http://bvb.ro/TradingAndStatistics/Publications/DailyReport\# (accessed on 2 August 2021).

84. Gino, F. Understanding ordinary unethical behavior: Why people who value morality act immorally. Curr. Opin. Behav. Sci. 2015, 3, 107-111. [CrossRef]

85. Uddin, M.N.; Hosen, M.; Chowdhury, S.A.; Chowdhury, M.M.; Alam Mazumder, M. Does Corporate Governance Influence the Firm Value in Bangladesh? A Panel Data Analysis. EM Econ. Manag. 2021, 24, 84-100. [CrossRef] 